DOI 10.22363/2312-8631-2018-15-1-63-72

UDK $378+517.9$

\title{
THE PHILOSOPHICAL ASPECT OF LEARNING INVERSE PROBLEMS OF MATHEMATICAL PHYSICS
}

\author{
V.S. Kornilov \\ Moscow city pedagogical university \\ Sheremetyevskaya str., 29, Moscow, Russia, 127521
}

The article describes specific questions student learning inverse problems of mathematical physics.

When teaching inverse problems of mathematical physics to the understanding of the students brought the information that the inverse problems of mathematical physics with a philosophical point of view are the problems of determining the unknown causes of known consequences, and the search for their solutions have great scientific and educational potential. The reasons are specified in the form of unknown coefficients, right side, initial conditions of the mathematical model of inverse problems, and as a consequence are functionals of the solution of this mathematical model.

In the process of learning the inverse problems of mathematical physics focuses on the philosophical aspects of the phenomenon of information and identify cause-effect relations. It is emphasized that in the process of logical analysis applied and humanitarian character, students realize that information is always related to the fundamental philosophical questions that the analysis applied and the humanitarian aspects of the obtained results the inverse problem of mathematical physics allows students to make appropriate inferences about the studied process and to, ultimately, new information, to study its properties and understand its value. Philosophical understanding of the notion of information opens up to students a new methodological opportunities to comprehend the world and helps us to reinterpret existing science and philosophy of the theory related to the disclosure of the interrelationship of all phenomena of reality.

Key words: learning inverse problems of mathematical physics, mathematical models, applied mathematics, information, philosophical sense of causality, a student

Modern scientific methods and approaches to exploring the diverse and multifaceted. The researcher, on the basis of professional knowledge and experience, goals and objectives, applies to knowledge of processes and phenomena, their causal relationships, scientific methods of world science are widely use at the same time, interdisciplinary scientific knowledge. Philosopher exploring the world through philosophical categories, a physicist with the help of physical experiments, a chemist with chemical experiments.

The same mathematician explores the world with the help of mathematical modeling, which are generally applicable equations of mathematical physics.

Currently, mathematical modeling, emerges as a new generic component of the methodology of any science. Published textbooks and scientific publications (see for example, $[2 ; 4 ; 9 ; 17 ; 21 ; 22 ; 27])$, in which covered such issues as subject, approaches, methods of mathematical modeling. In many textbooks and tutorials in various disciplines, provides concepts, methods and applications of mathematical modeling. In many 
universities that provide education in applied mathematics, are taught an academic discipline, the content of which includes mathematical modeling. It is widely known that mathematical models are a powerful method of learning about the world, as well as prediction and control, and allow you to grasp the essence of the studied phenomena.

Mathematical models are universal and can describe processes in objects of very different nature. Universalism enhances the cognitive power of mathematical models, opening up space for reasoning by analogy. The potential of mathematical modelling gained in the study of a range of tasks, can be applied to solving other problems. Well constructed mathematical model, as a rule, has an important property: its study provides new knowledge about the world.

On the modern stage is characterized by the integration of the sciences, the desire to get a more accurate idea of the total picture of the world. While the achievements of the modern sciences of nature that has educational value, can not be confined solely to scientists. The essence and practical role of scientific achievements needs to be disclosed at a level accessible to students of higher educational institutions. These ideas are reflected in the concept of modern higher education. But to solve this problem in one of the subject impossible. Therefore, in the theory and practice of teaching applied mathematics to implement the ideas of integration of disciplines.

Applied mathematical education is an important component of basic training students. The content of teaching applied mathematics has specific terminology, implemented interdisciplinary connections the study of university mathematics courses, mathematical models are used and the methods of their study. In the learning process students are offered learning objectives and tasks, the solution of which is fundamental, as subordinated to the principle of separation of the stages of rational discourse. In the course of such training is implemented by task approach, which provides the possibility of a mathematical and creative development of students and to build their competence in applied mathematics.

The block of disciplines of applied mathematics include such subjects as numerical methods, optimization methods, operations research, ordinary differential equations, partial differential equations, and other academic disciplines. In addition, it should be noted, and various special courses in applied mathematics, among them special courses on mathematical modeling, mathematical cybernetics, fractal sets, inverse and ill-posed problems.

The theory of inverse problems of mathematical physics as a scientific field of modern applied mathematics is widely used in applied research (see for example, $[6 ; 8 ; 9 ; 17 ; 23$; $24 ; 26]$ ). The rapid development of the theory and practice of inverse problems of mathematical physics is largely due to the possibility of effective research hard-to-reach or inaccessible objects and processes of different nature, determining their location, form, structure, inclusions, etc., revealing their causal relationships with the use of modern information and telecommunication technologies. According to V.G. Romanov, made in the 70-ies of XX century the theory of inverse problems, is the information and assumes the information-mathematical processing of information on the decision of the applied problems studied.

Inverse problems of mathematical physics with a philosophical point of view are the problems of determining the unknown causes of known consequences, and the search for their solutions have great scientific and educational potential. The reasons are specified 
in the form of unknown coefficients, right side, initial conditions of the mathematical model of inverse problems, and as a consequence are functionals of the solution of this mathematical model. Considering the wide application of the theory of inverse problems of mathematical physics for the study of applied problems in some Russian universities for students of the natural science areas of training are taught special courses on inverse problems of mathematical physics (see for example, $[3 ; 10-19 ; 24 ; 26]$ ). Depending on the professional orientation of training of students formed the content of such special courses.

During the training, students also study the inverse problem of determining coefficients or inhomogeneous parts, the boundary conditions of the mathematical model inverse problem other inverse problems. Such inverse problem can be considered for various equations of mathematical physics, among them hyperbolic, parabolic, elliptic, quasilinear, mixed, and other equations of mathematical physics. The desired function may depend on both one and many variables and may belong to different functional spaces. Depending on the considered mathematical models, such inverse problem can be univariate or multivariate, have mathematical characteristics and are usually incorrect.

These circumstances largely determine the choice of the scientific method of solving the inverse problem. During the study of inverse problems of mathematical physics widely used mathematical and functional analysis, scientific methods of integral equations, methods of partial differential equations, optimization methods, numerical methods and other methods applied and computational mathematics.

It is obvious that students have basic knowledge in the aforementioned subject areas will largely determine the effectiveness of teaching inverse problems of mathematical physics. In the process of training students not only learn mathematical methods and acquire skills for their application in the study of inverse problems for differential equations, but also provide fundamental knowledge on various subject areas of applied and computational mathematics.

It is widely known that the most important problems of modern applied mathematics is the analysis of the mathematical models, the distribution of the ideas of optimality, the increasing role of General mathematical structures, the spread of the ideas of optimality, algorithmization, strengthening business nature, humanization and other problems (see, for example, $[4 ; 7 ; 20 ; 21])$. Therefore, the implementation of interdisciplinary relations in learning inverse problems of mathematical physics to integrate scientific, humanistic and philosophical knowledge, which will help students to form scientific world Outlook, to understand the scientific, educational and humanitarian potential of inverse problems, to understand the cognitive processes in applied mathematics, to identify the basic concepts of several fundamental scientific disciplines, including Informatics, which plays a big role in the methodology of inverse problems. To such basic concepts of computer science are: information, modeling, formalization, algorithmization, computational experiment, syntax, semantics, computer graphics, information technology, and other basic computer science concepts.

In the process of learning the inverse problems of mathematical physics focuses on the philosophical aspects of the phenomenon of information, as well as identifying causal relationships. The study of the phenomenon of information devoted to the work of R.F. Abdeev, Aristotle, B.V. Biryukov, Y.A. Bolotov, N. Wiener, G.W.F. Hegel, 
V.M. Glushkov, V.B. Gukhman, I. Kant, A.N. Kolmogorov, V.V. Nalimov, G. Ryle, G.I. Ruzavin, A.E. Sedov, G. Haken, R. Hartley, D.S. Chernavsky, C. Shannon and other authors (see for example, $[1 ; 5 ; 6 ; 25 ; 28 ; 29]$ ).

To understand students brought information that on the basis of the notion of information became widespread thanks to the works of C. Shannon in the theory of communication and N. Wiener in the framework of cybernetics in the mid-twentieth century, there were questions the solution of which remains not only relevant for the creation of new information technologies, but also fully defines the development of many modern branches of human knowledge, including the theory of inverse problems of mathematical physics.

Students explained that in the 70-ies of XX century on the basis of cybernetic concepts appeared interpretation of information as a phenomenon associated with the nature and origin of life. In this case, information was understood as a fundamental property of nature, guaranteeing its ability to implement all the other properties defining the system as a living. The philosophical concept of information opens up to students a completely new methodological possibilities in the understanding of the world and helps us to reinterpret existing science and philosophy of the theory related to the disclosure of the interrelationship of all phenomena of reality.

In the process of logical analysis applied and humanitarian character, students realize that information is always related to the fundamental philosophical questions: the problem of the relation of being and thinking, this is a problem with the language, the functioning of the living and even inanimate nature, with problems of communication in human society and cyber sphere, with questions of creation and functioning of the artificial intellect, the problem of virtual reality and other philosophical questions. Analysis of applied and humanitarian aspects of the obtained results the inverse problem allows students to make appropriate inferences about the studied process and to, ultimately, new information, to study its properties and understand its value.

In the process of training students realize that the solution to the inverse problem of mathematical physics can provide new information, replacing direct measurement, while the solution of the direct problem, which is predetermined by a mathematical model and desired effects, do not give new information about the studied phenomenon, if studied external influence. However, the divergence of the solutions with experimental results can serve as a basis for the revision or refinement of the mathematical model of the inverse problem.

Implementation interscience ties when teaching inverse problems of mathematical physics allows students to establish fundamental knowledge in the theory and methodology of inverse problems, acquire skills of using mathematical methods for the study of applied problems. Allows students to carry out applied and humanitarian analysis of the solutions of inverse problems of mathematical physics, to develop scientific Outlook and mathematical creativity, enrich their scientific knowledge in applied and computational mathematics, but in basic concepts of informatics such as information, modeling, formalization, algorithmization, computational experiment, syntax, semantics, and other basic computer science concepts, as well as in fundamental concepts of philosophy, as cause, effect, philosophical phenomenon of information to understand their values and the role in cognition of the surrounding world. 
Realizing the philosophical aspects identified, the solution of inverse problems of causality and of the phenomenon given new information, the students realize that any science in which the final word is experiment, faced with the solution of inverse problems, which is a unity of theory and experiment and having regard to all the three methods of human cognition: theory, experiment and philosophy.

\section{LITERATURE}

[1] Абдеев Р.Ф. Философия информационной цивилизации. М.: Владос, 1994. 58 с.

[2] Ашихмин В.Н. Введение в математическое моделирование: учеб. пособие. М.: Логос, 2015. $440 \mathrm{c}$.

[3] Бидайбеков E.Ы., Корнилов В.С., Камалова Г.Б. Обучение будущих учителей математики и информатики обратным задачам для дифференциальных уравнений // Вестник Московского городского педагогического университета. Серия «Информатика и информатизация образования». 2014. № 3 (29). С. 57-69.

[4] Блехман И.М., Мышкис А.Д., Пановко Я.Г. Прикладная математика: предмет, логика, особенности подходов. М.: КомКнига, 2005. 376 с.

[5] Болотова Е.А. Информация как философская категория: онтологические и гносеологические аспекты: дисс. ... канд. филос. наук. Краснодар, 2005. 127 с.

[6] Бухгейм А.Л. Введение в теорию обратных задач. Новосибирск: Наука, Сибирское отделение, 1988. $181 \mathrm{c.}$

[7] Грекова И. Методологические особенности прикладной математики на современном этапе ее развития // Вопросы философии. 1976. № 6. С. 104-114.

[8] Корнилов В.С. О междисциплинарном характере исследований причинно-следственных обратных задач // Вестник Московского городского педагогического университета. Серия «Информатика и информатизация образования». 2004. № 1 (2). С. 80-83.

[9] Корнилов В.C. Некоторые обратные задачи идентификации параметров математических моделей: учеб. пособие. М.: МГПУ, 2005. 359 с.

[10] Корнилов В.С. Психологические аспекты обучения студентов вузов фрактальным множествам // Вестник Российского университета дружбы народов. Серия: Информатизация образования. 2011. № 4. С. 79-82.

[11] Корнилов В.C. Лабораторные занятия как форма организации обучения студентов фрактальным множествам // Вестник Московского городского педагогического университета. Серия «Информатика и информатизация образования». 2012. № 1 (23). С. 60-63.

[12] Корнилов B.C. Обратные задачи в содержании обучения прикладной математике // Вестник Российского университета дружбы народов. Серия: Информатизация образования. 2014. № 2. C. 109-118.

[13] Корнилов B.C. Обучение студентов обратным задачам математической физики как фактор формирования фундаментальных знаний по интегральным уравнениям / Бюллетень лаборатории математического, естественнонаучного образования и информатизации. Рецензируемый сб. науч. тр. Самара: Самарский филиал МГПУ, 2015. Т. VI. С. 251-257.

[14] Корнилов B.C. Обучение студентов обратным задачам для дифференциальных уравнений как фактор формирования компетентности в области прикладной математики // Вестник Российского университета дружбы народов. Серия: Информатизация образования. 2015. № 1. C. 63-72.

[15] Корнилов В.C. Реализация научно-образовательного потенциала обучения студентов вузов обратным задачам для дифференциальных уравнений // Казанский педагогический журнал. 2016. № 6. С. 55-59.

[16] Корнилов B.C. Базовые понятия информатики в содержании обучения обратным задачам для дифференциальных уравнений // Вестник Российского университета дружбы народов. Серия: Информатизация образования. 2016. № 1. С. 70-84. 
[17] Корнилов В.C. Теория и методика обучения обратным задачам для дифференциальных уравнений: монография. М.: Изд-во «ОнтоПринт», 2017. 500 с.

[18] Корнилов В.C. Формирование фундаментальных знаний по математическому моделированию при обучении обратным задачам для дифференциальных уравнений // Вестник Московского городского педагогического университета. Серия «Информатика и информатизация образования». 2017. № 1 (39). С. 92-99.

[19] Корнилов B.C. Обучение обратным задачам для дифференциальных уравнений как фактор развития научно-познавательного потенциала студентов // Вестник Московского городского педагогического университета. Серия «Информатика и информатизация образования». 2017. № 3 (41). С. 26-32.

[20] Левченко И.В., Корнилов В.С., Беликов В.В. Роль информатики в подготовке специалистов по прикладной математике // Вестник Московского городского педагогического университета. Серия «Информатика и информатизация образования». 2009. № 2 (18). С. 108 112.

[21] Малинецкий Г.Г. Управление риском. Риск, устойчивое развитие, синергетика. М.: Наука, $2000.431 \mathrm{c}$.

[22] Пашков Л.Т. Математические модели процессов в паровых котлах. М.: Институт компьютерных исследований, 2002. 208 с.

[23] Прилепко А.И. Избранные вопросы в обратных задачах математической физики // Условно-корректные задачи математической физики и анализа. Новосибирск: Наука, Сибирское отделение, 1992. С.151-162.

[24] Романов В.Г. Обратные задачи математической физики. М.: Наука, 1984. 264 с.

[25] Рузавин Г.И. Методология научного познания: учеб. пособие для вузов. М.: Юнита-Дана, 2012. $287 \mathrm{c}$.

[26] Самарский А.А., Вабишевич П.Н. Численные методы решения обратных задач математической физики. М.: УРСС, 2004. 478 с.

[27] Тарасевич Ю.Ю. Математическое и компьютерное моделирование. Вводный курс: учеб. пособие. М.: Едиториал УРСС, 2004. 149 с.

[28] Хакен $Г$. Информация и самоорганизация: макроскопический подход к сложным системам. M.: URSS, 2014. 317 c.

[29] Чернавский Д.С. Синергетика и информация. Динамическая теория хаоса. М.: Наука, 2001. $105 \mathrm{c}$.

(C) Kornilov V.S., 2017

\section{Article history:}

Received: 19 September, 2017

Accepted: 24 October, 2017

\section{For citation:}

Kornilov V.S. (2018) The philosophical aspect of learning inverse problems of mathematical physics. RUDN Journal of Informatization Education, 15 (1), 63-72. DOI 10.22363/2312-8631-201815-1-63-72

\section{Bio Note:}

Kornilov Viktor Semenovich, doctor of pedagogical sciences, candidate of physical and mathematical sciences, full professor, deputy head of the department of informatization of education of the Moscow city pedagogical university. Contact information: e-mail: vs_kornilov@mail.ru 


\title{
ФИЛОСОФСКИЙ АСПЕКТ ОБУЧЕНИЯ ОБРАТНЫМ ЗАДАЧАМ МАТЕМАТИЧЕСКОЙ ФИЗИКИ
}

\author{
В.С. Корнилов \\ Московский городской педагогический университет \\ Шереметьевская ул., 29, Москва, Россия, 127521
}

\begin{abstract}
В статье излагаются частные вопросы обучения студентов обратным задачам математической физики.

При обучении обратным задачам математической физики до понимания студентов доводятся сведения о том, что обратные задачи математической физики с философской точки зрения являются задачами определения неизвестных причин по известным следствиям, и поиски их решения обладают большим научно-познавательным потенциалом. При этом причины конкретизируются в виде неизвестных коэффициентов, правой части, начальных условий математической модели обратных задач, а в качестве следствий выступают функционалы от решения этой математической модели.

В процессе обучения обратным задачам математической физики уделяется внимание философским аспектам феномена информации и выявляемых причинно-следственных связей. Подчеркивается, что в процессе логического анализа прикладного и гуманитарного характера, студенты осознают, что информация всегда оказывается связанной с фундаментальными философскими вопросами, что анализ прикладных и гуманитарных аспектов полученных результатов обратной задачи математической физики позволяет студентам сделать соответствующие логические выводы об изучаемом процессе и получить, в конечном счете, новую информацию, изучить ее свойства и осмыслить ее ценность. Философское осмысление понятия информации открывает студентам новые методологические возможности в постижении мира и помогает по-новому осмыслить уже имеющиеся в науке и философии теории, связанные с раскрытием взаимосвязи всех явлений реальности.
\end{abstract}

Ключевые слова: обучение обратным задачам математической физики, математические модели, прикладная математика, информация, философский смысл причинно-следственных связей, студент

\section{REFERENCES}

[1] Abdeev R.F. Filosofija informacionnoj civilizacii [Front information the philosophy of civilization]. M.: Vlados, 1994. 58 p.

[2] Ashihmin V.N. Vvedenie v matematicheskoe modelirovanie [Introduction to Mathematical modeling]: uchebnoe posobie. M.: Logos, 2015. 440 p.

[3] Bidaibekov E. S., Kornilov V. S., Kamalova G. B. Obuchenie budushhih uchitelej matematiki i informatiki obratnym zadacham dlja differencial'nyh uravnenij [The training of future teachers of mathematics and Informatics inverse problems for differential equations]. Vestnik Moskovskogo gorodskogo pedagogicheskogo universiteta. Serija «Informatika i informatizacija obrazovanija» [Bulletin of the Moscow city pedagogical university. "Informatics and Informatization of Education" series]. 2014. No. 3 (29). Pp. 57-69.

[4] Blehman I.M., Myshkis A.D., Panovko Ja.G. Prikladnaja matematika:predmet, logika, osobennosti podhodov [Applied mathematics: the subject of logic, especially the approaches]. M.: KomKniga, 2005. $376 \mathrm{p}$.

[5] Bolotova E.A. Informacija kak filosofskaja kategorija: ontologicheskie i gnoseologicheskie aspekty [Computer science as a philosophical category: an ontological and epistemological aspects]: Dis. ... kand. filos. nauk. Krasnodar, 2005. 127 p. 
[6] Buhgejm A.L. Vvedenie v teoriju obratnyh zadach [Introduction to the theory of inverse problems]. Novosibirsk: Nauka, Sibirskoe otdelenie, 1988. 181 p.

[7] Grekova I. Metodologicheskie osobennosti prikladnoj matematiki na sovremennom jetape ee razvitija [Applied mathematical development of methodological its peculiarities at the present stage]. Voprosy filosofii [Problems of philosophy]. 1976. No. 6. Pp. 104-114.

[8] Kornilov V.S. O mezhdisciplinarnom haraktere issledovanij prichinno-sledstvennyh obratnyh zadach [About cross-disciplinary character of researches of cause and effect inverse problems]. Vestnik Moskovskogo gorodskogo pedagogicheskogo universiteta. Serija «Informatika i informatizacija obrazovanija» [Bulletin of the Moscow city pedagogical university. "Informatics and Informatization of Education" series]. 2004. No. 1 (2). Pp. 80-83.

[9] Kornilov V.S. Nekotorye obratnye zadachi identifikacii parametrov matematicheskih modelej [Some inverse problem of identifying parameters of mathematical models]: uchebnoe posobie. M.: MGPU, 2005. 359 p.

[10] Kornilov V.S. Psihologicheskie aspekty obuchenija studentov vuzov fraktal'nym mnozhestvam [Psychological aspects of training of students of higher education institutions in fractal sets]. Vestnik Rossijskogo universiteta druzhby narodov. Serija «Informatizacija obrazovanija» [Bulletin of the Russian university of friendship of the people. "Education Informatization" series]. 2011. No. 4. Pp. 79-82.

[11] Kornilov V.S. Laboratornye zanjatija kak forma organizacii obuchenija studentov fraktal'nym mnozhestvam [Laboratory sessions as a form of organization of teaching students fractal sets]. Vestnik Moskovskogo gorodskogo pedagogicheskogo universiteta. Serija «Informatika i informatizacija obrazovanija» [Bulletin of the Moscow city pedagogical university. "Informatics and Informatization of Education" series]. 2012. No. 1 (23). Pp. 60-63.

[12] Kornilov V.S. Obratnye zadachi v soderzhanii obuchenija prikladnoj matematike [Inverse problems in the content of teaching applied mathematics]. Vestnik Rossijskogo universiteta druzhby narodov. Serija «Informatizacija obrazovanija» [Bulletin of the Russian university of friendship of the people. "Education Informatization" series]. 2014. No. 2. Pp. 109-118.

[13] Kornilov V.S. Obuchenie studentovobratnym zadacham matematicheskojfiziki kak factor formirovanija fundamental'nyh znanij po integral'nym uravnenijam [Training of students in the inverse problems of mathematical physics as factor of formation of fundamental knowledge of the integrated equations]. Bjulleten' laboratorii matematicheskogo, estestvennonauchnogo obrazovanija i informatizacii. Recenziruemyj sbornik nauchnyh trudov [Bulletin of laboratory of mathematical, natural-science education and informatization. The reviewed collection of scientific work]. Samara: Samarskij filial MGPU, 2015. T. VI. Pp. 251-257.

[14] Kornilov V.S. Obuchenie studentov obratnym zadacham dlja differencial'nyh uravnenij kak faktor formirovanija kompetentnosti voblasti prikladnoj matematiki [Students learning the inverse problems for differential equations as a factor of formation of competence in the field of applied mathematics]. Vestnik Rossijskogo universiteta druzhby narodov. Serija «Informatizacija obrazovanija» [Bulletin of the Russian university of friendship of the people. "Education Informatization" series]. 2015. No. 1. Pp. 63-72.

[15] Kornilov V.S. Realizacija nauchno-obrazovatel'nogo potenciala obuchenija studentov vuzov obratnym zadacham dlja differencial'nyh uravnenij [Realization of scientific and educational potential of training of students of higher education institutions in the inverse problems for the differential equations]. Kazanskij pedagogicheskij zhurnal [Kazan pedagogical journal]. 2016. No. 6. Pp. 5559.

[16] Kornilov V.S. Bazovye ponjatija informatiki v soderzhanii obuchenija obratnym zadacham dlja differencial'nyh uravnenij [Basic computer science concepts in the learning content inverse problems for differential equations]. Vestnik Rossijskogo universiteta druzhby narodov. Serija «Informatizacija obrazovanija» [Bulletin of the Russian university of friendship of the people.

"Education Informatization" series]. 2016. No. 1. Pp. 70-84.

[17] Kornilov V.S. Teorija i metodika obuchenija obratnym zadacham dlja differencial'nyh uravnenij [Theory and technique of training to the inverse problems for differential equations]: monografija. M.: Izd-vo «OntoPrint», 2017. 500 p. 
[18] Kornilov V.S. Formirovanie fundamental'nyh znanij po matematicheskomu modelirovaniju pri obuchenii obratnym zadacham dlja differencial'nyh uravnenij [Formation of fundamental knowledge of mathematical modeling when training in the return tasks for the differential equations]. Vestnik Moskovskogo gorodskogo pedagogicheskogo universiteta. Serija «Informatika i informatizacija obrazovanija» [Bulletin of the Moscow city pedagogical university. "Informatics and Informatization of Education" series]. 2017. No. 1 (39). Pp. 92-99.

[19] Kornilov V.S. Obuchenie obratnym zadacham dlja differencial'nyh uravnenij kak faktor razvitija nauchno-poznavatel'nogo potenciala studentov [Learning inverse problems for differential equations as a factor of development of scientific and cognitive potential of students]. Vestnik Moskovskogo gorodskogo pedagogicheskogo universiteta. Serija «Informatika i informatizacija obrazovanija» [Bulletin of the Moscow city pedagogical university. "Informatics and Informatization of Education" series]. 2017. No. 3 (41). Pp. 26-32.

[20] Levchenko I.V., Kornilov V.S., Belikov V.V. Rol' informatiki v podgotovke specialistov po prikladnoj matematike [The role of Informatics in the training of specialists in applied mathematics]. Vestnik Moskovskogo gorodskogo pedagogicheskogo universiteta. Serija «Informatika i informatizacija obrazovanija» [Bulletin of the Moscow city pedagogical university. "Informatics and Informatization of Education" series]. 2009. No. 2 (18). Pp. 108-112.

[21] Malineckij G.G. Upravlenie riskom. Risk, ustojchivoe razvitie, sinergetika [Risk management. Risk, sustainable development, synergy]. M.: Nauka, 2000. 431 p.

[22] Pashkov L.T. Matematicheskie modeli processov v parovyh kotlah [Mathematical models of processes in steam boilers]. M.: Institut komp'juternyh issledovanij, 2002. 208 p.

[23] Prilepko A.I. Izbrannye voprosy v obratnyh zadachah matematicheskoj fiziki [Selected topics in inverse problems of mathematical physics]. Uslovno-korrektnye zadachi matematicheskoj fiziki $i$ analiza [Ill-posed problems of mathematical physics and analysis]. Novosibirsk: Nauka, Sibirskoe otdelenie, 1992. Pp.151-162.

[24] Romanov V.G. Obratnye zadachi matematicheskoj fiziki [Inverse problems of mathematical physics]: monografija. M.: Nauka, 1984. 264 p.

[25] Ruzavin G.I. Metodologija nauchnogo poznanija [The methodology of scientific knowledge]: uchebnoe posobie dlja vuzov. M.: Junita-Dana, 2012. 287 p.

[26] Samarskij A.A., Vabishevich P.N. Chislennye metody reshenija obratnyh zadach matematicheskoj fiziki [Numerical methods of the solution of the inverse problems of mathematical physics]: monografija. M.: Editorial URSS, 2004. 480 p.

[27] Tarasevich Ju.Ju. Matematicheskoe i komp'juternoe modelirovanie. Vvodnyj kurs [Mathematical and computer modeling. Introductory course]: uchebnoe posobie. M.: Editorial URSS, 2004. $149 \mathrm{p}$.

[28] Haken G. Informacija i samoorganizacija: makroskopicheskij podhod k slozhnym sistemam [Information and self-organization: a macroscopic approach to complex systems]. M.: URSS, 2014. $317 \mathrm{p}$.

[29] Chernavskij D.S. Sinergetika i informacija. Dinamicheskaja teorija haosa [Synergetics and information. Dynamic chaos theory]. M.: Nauka, 2001. 105 s.

\section{История статьи:}

Дата поступления в редакцию: 19 сентября 2017

Дата принятия к печати: 24 октября 2017

Для цитирования:

Корнилов В.С. Философский аспект обучения обратным задачам математической физики // Вестник Российского университета дружбы народов. Серия «Информатизация образования». 2018. T. 15. № 1. C. 63-72. DOI 10.22363/2312-8631-2018-15-1-63-72 


\section{Сведения об авторе:}

Корнилов Виктор Семенович, доктор педагогических наук, кандидат физико-математических наук, профессор, заместитель заведующего кафедрой информатизации образования Московского городского педагогического университета. Контактная информация: e-mail: vs_kornilov@mail.ru 